\title{
Evaluation of free radical scavenging activity of Neiebuhria apetala DUNN leaf extracts
}

\author{
${ }^{1}$ A. Balamurugan, ${ }^{2}$ A. Doss, ${ }^{1}$ B. Parthipan, ${ }^{* 2}$ V.R. Mohan \\ ${ }^{1}$ Research Scholar (Reg. No. 12621), PG \& Research Department of Botany, ST.Hindu College, Nagercoil, Tamilnadu \\ ${ }^{2}$ Ethnopharmacology Unit, PG \& Research Department of Botany, V.O.Chidambaram College, Tuticorin, Tamilnadu \\ Affiliated to Manonmaniam Sundaranar University, Abishekapatti, Tirunelveli, Tamilnadu, India \\ *Corresponding author::vrmohanvoc@gmail.com
}

Available online at: www.isroset.org

Accepted: 25/Aug/2018, Online: 30/Aug/ 2018

\begin{abstract}
The present investigation is to assess the antioxidant properties of leaf extracts of Neiebuhria apetala using different in vitro methods. The antioxidant activity was studied by DPPH radical scavenging method, hydroxyl radical scavenging activity, superoxide radical scavenging activity, ABTS radical scavenging activity and reducing power methods. Ethanol extract of leaf showed very good antioxidant properties. The present study exposed that ethanol extract of $\mathrm{N}$. apetala include effective potential source of natural antioxidant, which might be useful in preventing the progress of various oxidative stresses.
\end{abstract}

Keywords- Medicinal plants, ROS, Antioxidant activity, DPPH, Superoxide assay

\section{INTRODUCTION}

Free radicals such as oxygen, superoxide and hydroxyl are biologically important substances which naturally release from human tissues. The highly reactive radicals can cause oxidative damage to DNA, lipids and proteins [1]. Therefore, free radicals result in many disorders like cancer, cardiovascular diseases and diabetes mellitus [2]. Many compounds carried out free radical scavenging are substances having antioxidant activity such as flavonoid and phenolic compounds or phenolic rich plant extracts. Ascorbic acid, the standard antioxidant in this study, acts as a chain breaking scavenging agent that impairs the formation of free radicals in the process of intracellular substances formation throughout the body, including collagen bone matrix and tooth [3]. Several methods have been developed to estimate the antioxidant capacity of different plant materials [4]. A single assay is not sufficient to evaluate the total antioxidant activity [5].

Capparis species is also known as Caper plants. These are familiar as a potential cause of valuable nutrients and biochemical compounds with physiological function. The multiple biological activities includes antibacterial, antifungal, hepatoprotective, anthelmintic, antidiabetic, antiinflammatory, anti-cancer, and antihyperlipidemic. These activities as well as folk medicinal uses of Caper plants have been attributed to the presence of functional bioactives, such as phenolic acids, flavonoids, alkaloids, phytosterols, natural sugars, vitamins, and organic acids [6]. Hence the present study, different solvent extracts of $N$. apetala leaf was investigated for their antioxidant activity using DPPH radical scavenging activity, hydroxyl radical scavenging activity, superoxide scavenging activity, ABTS radical cation scavenging activity and reducing power assay.

\section{RELATED WORK}

Presently, more interest has been focused on the use of natural remedies to protect the human body especially brain tissues from the oxidative damage caused by free radicals. For the past two decades, several medicinal plants have shown such effectiveness through the traditional methods of ethnopharmacology. Keeping this in view, the present study has been conducted to evaluate the comparative antioxidant activity of folklore medicinal plant $(N$. apetala) which are traditionally used to treat various diseases.

\section{MATERIALS AND METHODS}

\section{Collection of plants}

The fresh plant parts of $N$. apetala (leaf) were collected from Petchiparai, Western Ghats, Kanyakumari District, Tamil Nadu, India. The gathered samples were cut into small pieces and shade dried until the fracture is identical and even. The dried plant material was crushed or grinded by using a blender and separated to get uniform particles by using sieve No. 60. The final uniform powder was used for the extraction of active constituents of the plant material. 


\section{Preparation of extract}

$100 \mathrm{~g}$ of the coarse powder of $N$. apetala leaf was extracted successively with $250 \mathrm{ml}$ of alcoholic and organic solvents (Peroleum ether, Benzene, Ethyl acetate, Methanol and Ethanol) in a Soxhlet apparatus for $24 \mathrm{hrs}$. All the extracts were filtered through Whatman No. 41 filter paper separately and all the extracts were concentrated in a rotary evaporator. All the concentrated extracts were subjected for in vitro antioxidant activity.

\section{Antioxidant activity \\ DPPH radical scavenging activity}

The DPPH is a constant free radical and is extensively used to measure the radical scavenging activity of antioxidant component. This process is based on the reduction of DPPH in methanol solution in the company of a hydrogen donating antioxidant due to the arrangement of the non-radical form DPPH-H [7]. Using 1, 1- diphenyl-2-picrylhydrazyl (DPPH) the free radical scavenging action of all the extracts was assessed as per the previously reported process [7]. DPPH of $0.1 \mathrm{mM}$ solution in methanol was prepared. 1 $\mathrm{ml}$ of this solution was poured into $3 \mathrm{ml}$ of the solution at different concentrations $(50,100,200,400$ and $800 \mu \mathrm{g} / \mathrm{ml})$. The mixtures were shaken dynamically and allowed to stand at room temperature for 30 minutes. After that the absorbance was measured at $517 \mathrm{~nm}$ using a UV-VIS spectrophotometer (Genesys 10s UV: Thermo electron corporation). Ascorbic acid was employed as the reference. The lesser absorbance values of reaction mixture identify higher free radical scavenging action. Using the subsequent formula the ability to scavenge the DPPH radical was computed.

\section{/ A0 X 100}

DPPH scavenging effect $(\%$ inhibition $)=(\mathrm{A} 0-\mathrm{A} 1)$

Where, A0 is the absorbance of the control and A1 is the absorbance of the test samples and reference. All the tests were carried out in triplicates and the outcomes were averaged.

\section{Hydroxyl radical scavenging activity}

According to the modified method of Halliwell et al. [8] the scavenging ability for hydroxyl radical was projected. Stock answers of $\mathrm{FeCl}_{3}(10 \mathrm{mM})$, Ascorbic Acid $(1 \mathrm{mM})$, EDTA $(1 \mathrm{mM}), \mathrm{H} 2 \mathrm{O} 2(10 \mathrm{mM})$ and Deoxyribose $(10 \mathrm{mM})$ were put in distilled deionized water. The assay was executed by adding $0.1 \mathrm{ml}$ EDTA, $0.1 \mathrm{ml} \mathrm{H}_{2} \mathrm{O}_{2}, 0.01 \mathrm{ml}$ of $\mathrm{FeCl} 3,0.36$ $\mathrm{ml}$ of deoxyribose, $1.0 \mathrm{ml}$ of the extract of diverse concentration $(50,100,200,400 \& 800 \mu \mathrm{g} / \mathrm{ml})$ dissolved in distilled water, $0.33 \mathrm{ml}$ of phosphate buffer $(50 \mathrm{mM}, \mathrm{pH} 7.9)$, $0.1 \mathrm{ml}$ of ascorbic acid in sequence. The mixture was then incubated at $37^{\circ} \mathrm{C}$ for 1 hour. $1.0 \mathrm{ml}$ of the incubated mixture was mixed with $1.0 \mathrm{ml}$ of $10 \%$ TCA and $1.0 \mathrm{ml}$ of $0.5 \%$ TBA (in $0.025 \mathrm{M} \mathrm{NaOH}$ containing $0.025 \% \mathrm{BHA}$ ) to develop the pink chromogen measured at $532 \mathrm{~nm}$. The hydroxyl radical scavenging achievement of the extract is accounted as \% inhibition of deoxyribose. The degradation is figured by using the succeeding equation
Hydroxyl radical scavenging activity $=($ A0 - A1) $/$ A0 X 100 where, $\mathrm{A} 0$ is the absorbance of the control and A1 is the absorbance of the test samples and reference. All the tests were carried out in triplicates and the results were averaged.

\section{Superoxide radical scavenging activity}

The superoxide anion scavenging action was calculated as elucidated by Srinivasan et al. [9]. The superoxide anion radicals were made in $3.0 \mathrm{ml}$ of Tris - $\mathrm{HCl}$ buffer (16 mM, pH 8.0) containing $0.5 \mathrm{ml}$ of NBT $(0.3 \mathrm{mM})$, $0.5 \mathrm{ml}$ NADH $(0.936 \mathrm{mM})$ solution, $1.0 \mathrm{ml}$ extract of different concentrations $(50,100,200,400 \& 800 \mu \mathrm{g} / \mathrm{ml})$ and $0.5 \mathrm{ml}$ Tris - $\mathrm{HCl}$ buffer $(16 \mathrm{mM}, \mathrm{pH} 8.0)$. The reaction was started by adding $0.5 \mathrm{ml}$ PMS solution $(0.12 \mathrm{mM})$ to the mixture, incubated at $25^{\circ} \mathrm{C}$ for $5 \mathrm{~min}$ and the absorbance was estimated at 560nm against a blank sample, ascorbic acid. The percentage inhibition was determined by using the following equation

Superoxide radical scavenging activity $=(\mathrm{A} 0-\mathrm{A} 1) / \mathrm{A} 0 \mathrm{X}$ 100

where, A0 is the absorbance of the control and A1 is the absorbance of the test samples and reference. All the tests were achieved in triplicates and the results were averaged.

\section{Antioxidant Activity by Radical Cation (ABTS+)}

ABTS assay was supported on the slightly modified technique of Huang et al. [10]. By reacting $7 \mathrm{mM}$ ABTS solution with $2.45 \mathrm{mM}$ potassium persulphate, ABTS radical cation (ABTS+) was prepared. This mixture is permitted to be in the dark at room temperature for $12-16 \mathrm{hrs}$ previous to use. With ethanol to an absorbance of $0.70+0.02$ at $734 \mathrm{~nm}$ the ABTS+ solution was added. Following this trolox standard to $3.9 \mathrm{ml}$ of diluted ABTS+ solution or addition of $100 \mu \mathrm{L}$ of sample, absorbance was calculated at $734 \mathrm{~nm}$ by Genesys 10S UV-VIS (Thermo scientific) accurately after 6 minutes. Results were expressed as trolox equivalent antioxidant capacity (TEAC).

$\mathrm{ABTS}$ radical cation activity $=(\mathrm{A} 0-\mathrm{A} 1) / \mathrm{A} 0 \mathrm{X} 100$ where, $\mathrm{A} 0$ is the absorbance of the control and $\mathrm{A} 1$ is the absorbance of the test samples and reference. All the tests were repeated thrice and the end results were averaged.

\section{Reducing Power}

The reducing power of the extract was established by the method of Kumar and Hemalatha [11]. $1.0 \mathrm{ml}$ of solution containing $50,100,200,400 \& 800 \mu \mathrm{g} / \mathrm{ml}$ of extract was mixed up with sodium phosphate buffer $(5.0 \mathrm{ml}, 0.2 \mathrm{M}$, $\mathrm{pH}$ 6.6) and potassium ferricyanide $(5.0 \mathrm{ml}, 1.0 \%)$. The mixture was incubated at $50^{\circ} \mathrm{C}$ for 20 minutes. Then $5 \mathrm{ml}$ of $10 \%$ trichloroacetic acid was added and centrifuged at $980 \mathrm{~g}$ $\left(10\right.$ minutes at $\left.5^{\circ} \mathrm{C}\right)$ in a refrigerated centrifuge. The upper layer of the solution $(5.0 \mathrm{ml})$ was diluted with $5.0 \mathrm{ml}$ of distilled water and ferric chloride and absorbance read at 700 $\mathrm{nm}$. The experiment was performed thrice and results were averaged. 


\section{RESULTS AND DISCUSSION}

\section{DPPH radical scavenging activity}

The antioxidant activity of crude leaf extracts of $N$. apetala were tested using the constant free radical, DPPH. Unlike DPPH radical scavenging is considered to be good in vitro model widely used to assess antioxidant efficacy within a very short time. In its radical form, DPPH disappears on reduction by an antioxidant compound or a radical species to become a stable diamagnetic molecule resulting in the color change from purple to yellow, due to the formation of diphenyl picryl hydrazine, which could be taken as an indication of the hydrogen donating ability of the tested samples [12]. DPPH radical scavenging activity of petroleum ether, benzene, ethyl acetate, methanol and ethanol extracts of leaf of $N$. apetala are shown in figure 1. The scavenging effect of ascorbic acid, the standard and various solvent extracts studied increases with the increase in the concentration. Among the solvent tested, ethanol extract leaf of $N$. apetala exhibited the highest DPPH radical scavenging activity. At $800 \mu \mathrm{g} / \mathrm{ml}$ concentration, ethanol extract of leaf of $N$. apetala possessed $128.22 \%$. The concentration of $N$. apetala leaf ethanol extract needed for $50 \%$ inhibition $\left(\mathrm{IC}_{50}\right)$ was $32.43 \mathrm{mg} / \mathrm{ml}$, while ascorbic acid needed $29.16 \mathrm{mg} / \mathrm{ml}$ (Table 1).

\section{Hydroxyl radical scavenging activity}

Hydroxyl radical scavenging activity of petroleum ether, benzene, ethyl acetate, methanol and ethanol extracts of leaf of $N$. apetala are shown in figure 2. The methanol extract of $N$. apetala leaf showed a very potent hydroxyl radical scavenging activity. At $800 \mu \mathrm{g} / \mathrm{ml}$ concentration, $N$. apetala leaf possessed $138.16 \%$ hydroxyl radical scavenging activity. The concentration of $N$. apetala leaf methanol extract needed for $50 \%$ inhibition $\left(\mathrm{IC}_{50}\right)$ was found to be $37.16 \mathrm{mg} / \mathrm{ml}$, whereas $28.17 \mathrm{mg} / \mathrm{ml}$ (Table 1) needed for ascorbic acid. The hydroxyl radical scavenging ability of the extracts was determined by its ability to compete with deoxyribose for hydroxyl radical. The crude extracts (methanol) of $N$. apetala extract compete with deoxyribose and diminish chromogen formation in a dose dependant manner. In this assay, 2-deoxy-2-ribose was oxidized when exposed to hydroxyl radicals generated by Fenton-type reaction. Scavenging of $\mathrm{OH}+$ is an important antioxidant activity, because of its very high reactivity, which can easily cross the cell membranes at specific sites and reacts with most of the biomolecules and furthermore cause tissue damage and cell death. Thus, removing $\mathrm{OH}+$ is very important task for the protection of living systems [13].

\section{Superoxide anion radical scavenging activity}

All the extracts of $N$. apetala leaf were subjected to be superoxide radical scavenging activity and the results are shown in figure 3 . The ethanol extract of leaf of $N$. apetala exhibited the maximum superoxide radical scavenging activity $138.22 \%$ at $800 \mu \mathrm{g} / \mathrm{ml}$ concentration. This scavenging activity was higher than that of ascorbic acid, the standard which had $119.61 \%$ scavenging activity. The $\mathrm{IC}_{50}$ value of ethanol extract of $N$. apetala leaf on superoxide radical was found to be $36.93 \mathrm{mg} / \mathrm{ml}$ and $30.16 \mathrm{mg} / \mathrm{ml}$ for ascorbic acid, respectively (Table 1). Superoxide anions are the most common free radicals in in vivo and are generated in a variety of biological systems and the concentration of superoxide anions increases under conditions of oxidative stress. Superoxide anion is a reduced form of molecular oxygen created by receiving one electron. Superoxide anion is an initial free radical from mitochondrial electron transport systems. Mitochondria generate energy using a 4-electron chain reaction, reducing oxygen to water. Some of the electrons escaping from the chain reaction of mitochondria directly react with oxygen and form superoxide anion. It plays an important role in the formation of other reactive oxygen species, such as hydrogen peroxide, hydroxyl radical or singlet oxygen in living systems [14].

\section{ABTS radical cation scavenging activity}

The different solvent extracts of $N$. apetala leaf were subjected to be ABTS radical cation scavenging activity and the results are shown in figure 4 . The methanol extract of $N$. apetala leaf exhibited potent ABTS radical cation scavenging activity in concentration dependent manner. At $800 \mu \mathrm{g} / \mathrm{ml}$ concentration, the methanol extract of $N$. apetala leaf possessed $128.16 \%$. The quantity of $N$. apetala methanol extract required to produce $50 \%$ inhibition of ABTS radical $32.07 \mathrm{mg} / \mathrm{ml}$ whereas $30.22 \mathrm{mg} / \mathrm{ml}$ (Table 1) needed for trolox. The ABTS chemistry involves direct generation of ABTS radical mono cation with no involvement of any intermediary radical. It is a decolorization assay, thus the radical cation is performed prior to addition of antioxidant test system, rather than the generation of the radical taking place continually in the presence of antioxidant. The results obtained imply the activity of the extract either by inhibiting or scavenging the ABTS radicals since both inhibition and scavenging properties of antioxidants towards ABTS radicals have been reported earlier [15].

\section{Reducing Power}

Table 5 showed the reducing abilities of different solvent extracts of $N$. apetala leaf were compared to the standard ascorbic acid. Absorbances of the extracts were increased with the concentration. A higher absorbance indicated a higher reducing power. Among the solvent tested, the methanol extracts of leaf of $N$. apetala exhibited higher reducing activity. This result indicates that the extracts may consist of polyphenolic compounds that usually show great reducing power. This has been justified by methanol extract being the most reducing agent with highest phenolic content. Reducing power assay measures the electron-donating capacity of an antioxidant [16]. In this assay, the yellow color of the test solution changes to various shades of green and blue, depending on the reducing power of each compound. Presence of reducers causes the conversion of the 
Fe3+/ferricyanide complex to the ferrous form used in this method may serve as a significant indicator of its antioxidant capacity $[17,18]$.

\section{CONCLUSION}

The results of the present study revealed that $N$. apetala leaf extracts possessed potent free radical scavenging ability in methanol and ethanol extracts. The activity observed may be attributed to the presence of phenolic and flavaniod contents in the methanol and ethanol extracts and further we conclude that this plant is a potential candidate for natural antioxidant.

\section{REFERENCES}

[1] A.D. Boveris, M. Galleano, S. Puntarulo, S, "In vivo supplementation with Ginkgo biloba protects membranes against lipid peroxidation", Phytotherapy Research, Vol. 21, pp: 735-740, 2007.

[2] J. Vaya, M. Aviram, "Nutritional antioxidants mechanisms of action, analyses of activities and medical applications", Current Medical. Chem. Immunol. Endocrine Metabolic Agents. Vol.1, pp: 99-117, 2001.

[3] F. Aqil, I. Ahmed, Z. Mehmood, "Antioxidant and free radical scavenging properties of twelve traditionally used Indian medicinal plant", Turkey Journal of Biology, Vol. 30, pp: 177-183, 2006.

[4] C. Guo, J. Yang, J. Wei, Y. Li, J. Xu, Y. Jiang, "Antioxidant activities of peel, pulp and seed fractions of common fruits as determined by FRAP assay", Nutrition Research, Vol.23, pp: 17191726, 2003.

[5] E.M. Silva, J.N.S. Souza, H. Rogez, J.F. Rees, Y. Larondella, Y, "Antioxidant activities and polyphenolic contents of fifteen selected plant species from the Amazonian region", Food Chemistry, Vol. 101, pp: 1012-1018, 2006.

[6] R.R. Ambati, S.M. Phang, S.Ravi, R.G. Aswathanarayana, "Astaxanthin: Sources, extraction, stability, biological activities and its commercial applications - A review", Marine Drugs, Vol. 12, pp: 128-152, 2014.

[7] M.S. Blois, "Antioxidant determination by the use of a stable free radical", Nature, Vol. 181, pp: 1199- 1200, 1958.
[8] B. Halliwell, J.M.C. Gutteridge, O.I. Aruoma, "The deoxyribosemethod: a simple 'test tube' assay for determination of rateconstants for reaction of hydroxyl radicals", Anals of Biochemistry, Vol:165, pp:215-219, 1987.

[9] R. Srinivasan, M.J.N. Chandrasekar, M.J.Nanjan, B.Suresh," Antioxidant activity of Caesalpinia digyna root", Journal of Ethnopharmacology, Vol.113, pp: 284-291, 2007.

[10] M.H. Huang, S.S. Huang, B.S. Wang, C.H.Wu, M.J. Sheu,W.C. Hou, S.S. Lin, G.J. Huang,"Antioxidant and anti-inflammatory properties of Cardiospermum halicacabum and its reference compounds ex vivo and in vivo", Journal of Ethnopharmacology, Vol. 133,pp: 743-750, 2011.

[11] R.S. Kumar, S. Hemalatha,"In vitro antioxidant activity of alcoholic leaf extract and subfractions of Alangium lamarckii Thwaites", Journal of Chemical and Pharmaceutical Research, Vol.3, pp: 259267, 2011

[12] Y.R. Lee, K.S.Woo, K.J. Kim, J.R. Son, H.S. Jeong, “Antioxidant activities of ethanol extracts from germinated specialty rough rice", Food Science and Biotechnology, Vol. 16, pp: 765-770, 2007.

[13] J. Yang, J. Guo, J. Yuan, "In vitro antioxidant properties of rutin. Lebensm", Wissenschaft Technology, Vol. 41, pp: 1060-1066, 2008.

[14] J. Lee, N.Koo, D.B. Min, "Reactive oxygen species, aging and antioxidative nutraceuticals. Comphre" Reviews in Food Science and Food Safety, Vol.3, pp: 21-33, 2004.

[15] R. Re, N. Pellegrimi, A.Proleggenke, A. Pannala, M. Yang, RiceEvans, "Antioxidant activity applying an improved ABTS radical cation decolorization assay", Free Radical Biology and Medicine. 26: 1231-1237, 1999.

[16] H.R.D. Hinneburg, Dorman, R. Hiltunen, "Antioxidant activities of extracts from selected culinary herbs and spice", Food Chemistry, Vol. 97, pp: 122-129, 2006.

[17] A. Yildirim, A. Mavi, M.Oktay, A.A. Kara, O.F.Algur, V. Bilaloglu," Comparison of antioxidant and antimicrobial activities of Tilia (Tilia argentea Desf Ex DC), Sage (Salvia triloba L.), and bark Tea (Camellia sinensis) extracts", Journal of Agirculture and Food Chemistry, Vol. 48, pp: 5030-5034, 2000.

[18] R. Amarowicz, R. Pegg, P. Rahimi-Moghaddam, B. Barl, J. Weil, "Free radical scavenging capacity antioxidant activity of selected plant species from the Canadian prairies", Food Chemistry, Vol. 84, pp: 551-562, 2004.

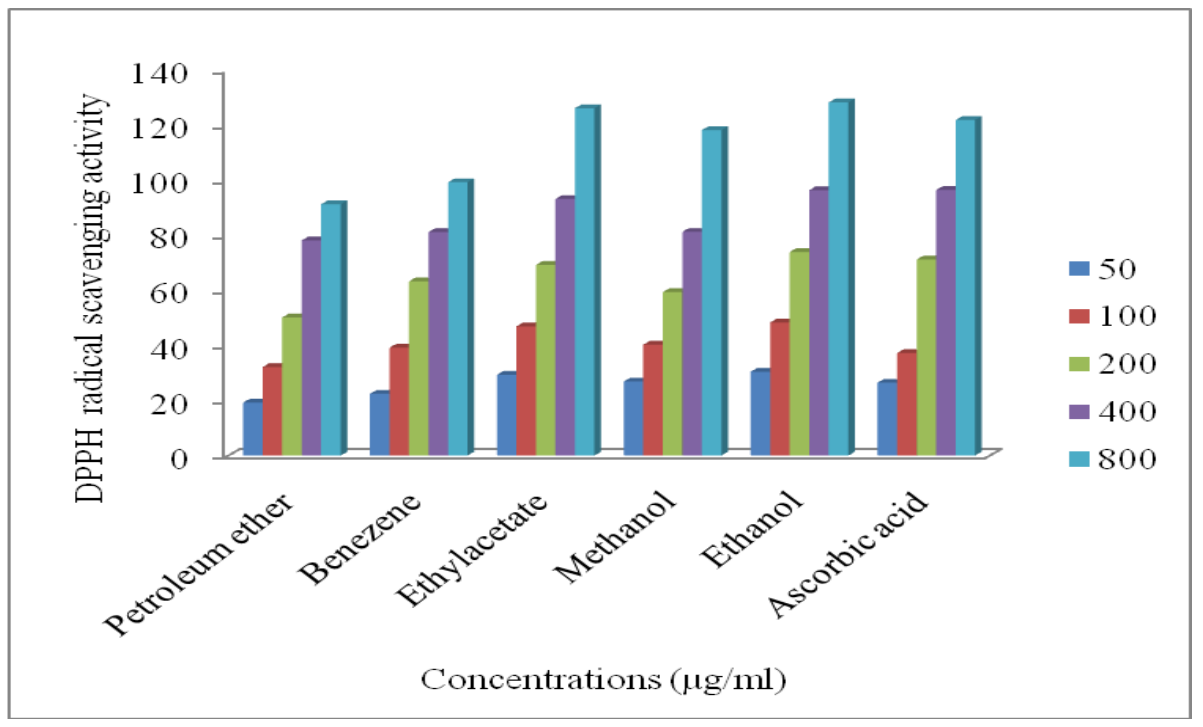

Figure 1: Effect of different solvent extract of $N$. apetals leaf on DPPH assay 


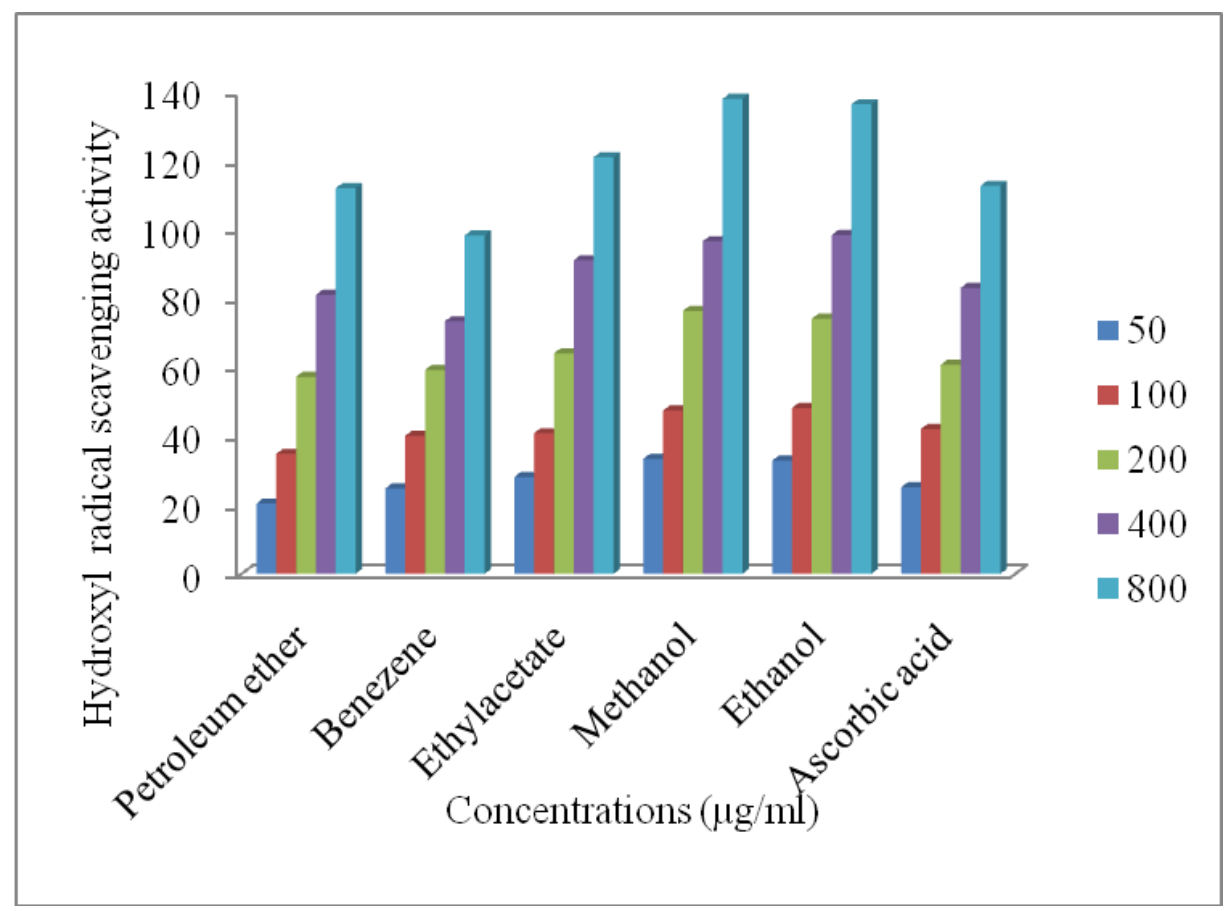

Figure 2: Effect of different solvent extract of $N$. apetals leaf on Hydroxyl assay

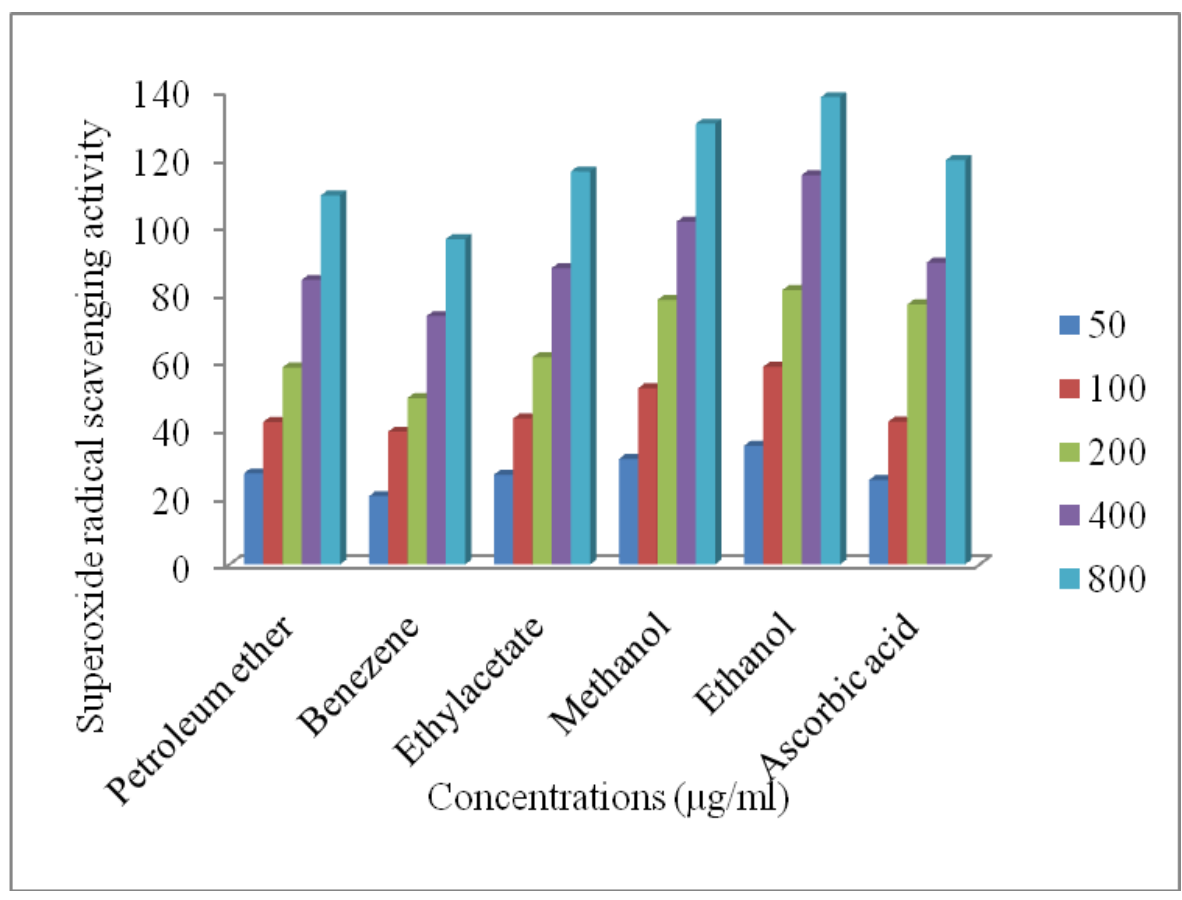

Figure 3: Effect of different solvent extract of $N$. apetals leaf on Superoxide anion assay 


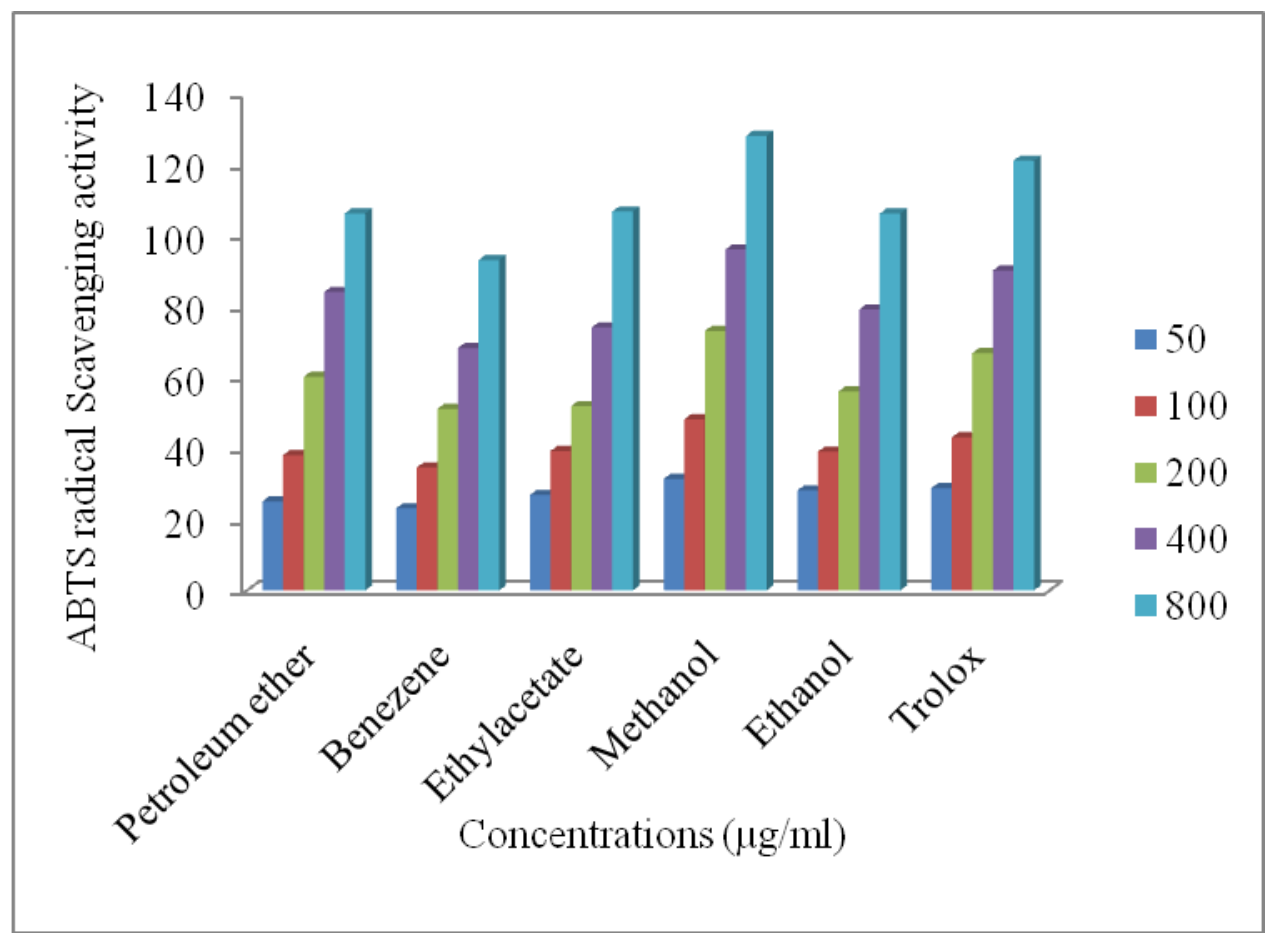

Figure 4: Effect of different solvent extract of $N$. apetals leaf on ABTS assay

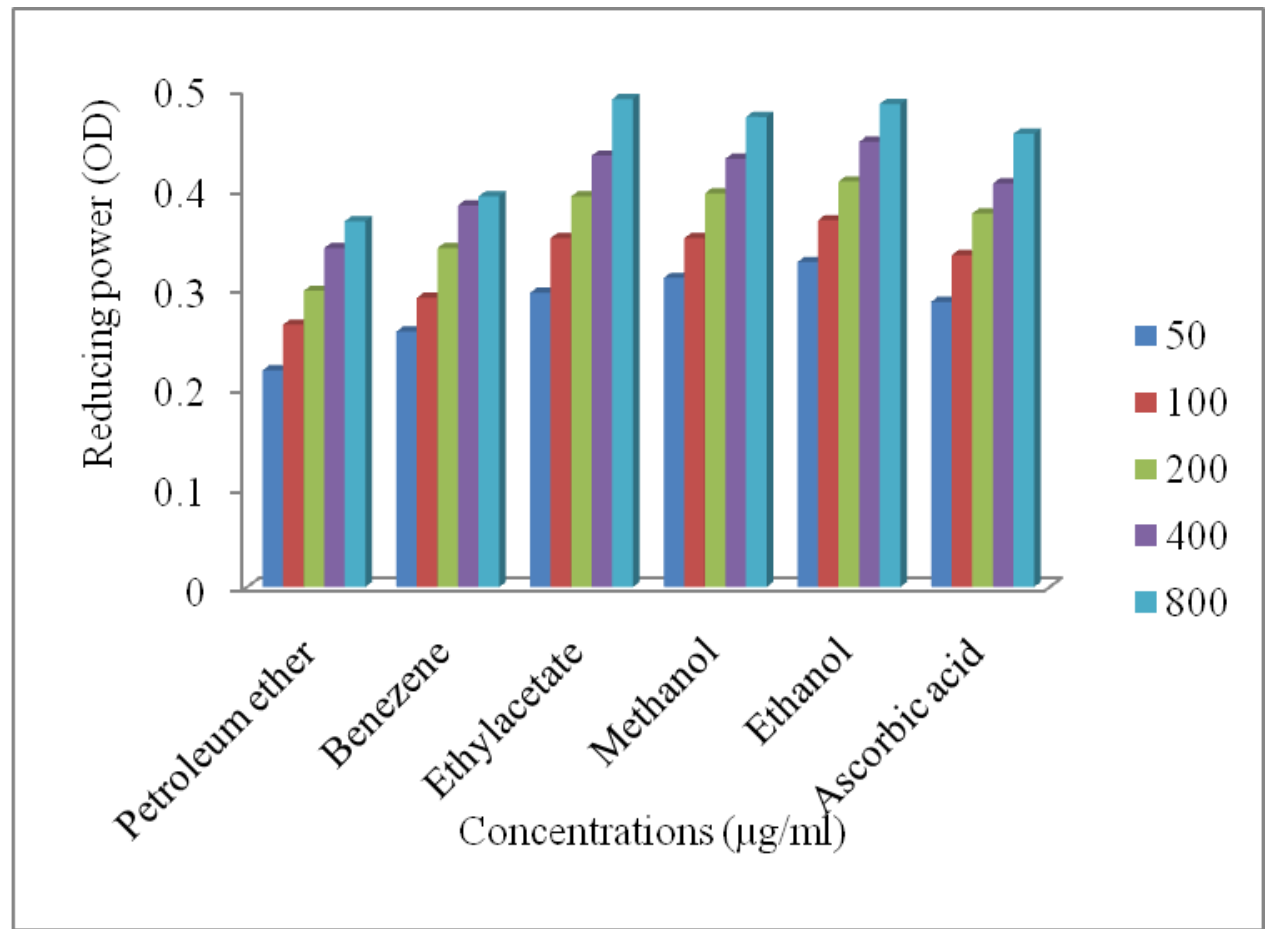

Figure 5: Effect of different solvent extract of $N$. apetals leaf on reducing power assay 
Table 1: $\mathrm{IC}_{50}$ values of different solvent extracts of the leaf extracts of $N$. apetals

\begin{tabular}{|c|c|c|c|c|}
\hline \multirow{2}{*}{ Solvents } & \multicolumn{4}{|c|}{ IC $\mathbf{5 0}(\boldsymbol{\mu g} / \mathbf{m l})$} \\
\cline { 2 - 5 } & DPPH & Hydroxyl & ABTS & Superoxide anion \\
\hline P.ether & 24.11 & 27.91 & 26.97 & 24.93 \\
\hline Benzene & 26.16 & 26.23 & 23.06 & 28.95 \\
\hline Ethyl acetate & 31.84 & 31.45 & 27.07 & 34.22 \\
\hline Methanol & 28.16 & 37.16 & 32.07 & 36.93 \\
\hline Ethanol & 32.43 & 36.54 & 27.12 & 30.16 \\
\hline Ascorbic acid & 29.16 & 28.17 & - & - \\
\hline Trolox & - & - & 30.22 & \\
\hline
\end{tabular}

